\title{
Dampak Sistem Tanam Paksa terhadap Dinamika Perekonomian Petani Jawa 1830-1870
}

\author{
HENDRA KURNIAWAN \\ Universitas Sanata Dharma Yogyakarta \\ hendrayang7@gmail.com
}

\begin{abstract}
Abstrak
Penelitian ini bertujuan mengeksplorasi dampak sistem tanam paksa terhadap Dinamika Perekonomian Petani Jawa Tahun 1830-1870. Metode penelitian menggunakan studi literatur. Hasil penelitian menunjukkan bahwa pasca bubarnya kongsi dagang VOC menimbulkan kebijakan baru di Hindia Belanda. Atas berbagai pertimbangan ekonomi maka pemerintah kolonial Belanda melaksanakan Sistem Tanam Paksa(Cultuurstelsel) dalam kurun waktu hampir 50 tahun. Sistem ini membawa banyak perubahan dalam kehidupan petani di Jawa.Sistem Tanam Paksa telah mengenalkan petani pada sistem tanam yang lebih modern. Kondisi ini membuat ekonomi pangan memiliki pondasi yang semakin mantap. Pada masa ini pula terbuka peluang bagi tumbuhnya ekonomi masyarakat tani. Perekonomian subsisten perlahan bergeser menjadi perekonomian uang. Akan tetapi bagaimanapun penyimpangan dalam pelaksanaan Tanam Paksa pada akhirnya semakin menambah derita penduduk jajahan.
\end{abstract}

Kata kunci:tanam paksa, perekonomian, petani Jawa

\begin{abstract}
This research aims to eksplore the effects of cultuurstelsel system on the dynamics of Javanese farmers in 1830-1870. This research utilizes literature study method. The resesrch findings show that after VOC trade partnership had dispersed, a new law was made in the Dutch East Indies. Due to some economic considerations, the Dutch Colonial Government implemented Cultuurstelsel system for almost fifty years. This system brought a lot of changes for Javanese farmers' life. This system introduced farmers to the modern ways of rice fields cropping. This condition stabilized the foundation of economy. During this time, the chance for farmers to develop is widely opened. The subsistence economy slowly changed into money-oriented economy. However, at the end, the deviations of the cultuurstelsel system increased the misery of colonized residents.
\end{abstract}

Keywords: cultuurstelsel system, economy, Javanese farmers 


\section{PENDAHULUAN}

VOC (Vereenigde Oost-Indische Compagnie) atau Persekutuan Dagang Hindia Belanda yang didirikan pada bulan Maret 1602 menjadi awal cikal bakal penguasaan Belanda atas wilayah Indonesia. VOC berdiri atas keinginan kongsi-kongsi dagang dari Belanda yang berdatangan ke Indonesia dalam kurun waktu tahun 1595 sampai 1600-an. Kongsi dagang itu berasal dari Amsterdam, Middelburg, Rotterdam, Zeeland, Delft, Enkhuizen, dan Hoorn (Sartono Kartodirdjo, 1993:70). Pimpinan VOC terdiri dari tujuh belas anggota yang merupakan perwakilan dari kongsikongsi dagang yang disebut sebagai Heeren Zeventien atau Tuan-tuan XVII.

Menjelang akhir abad XVIII VOC mengalami kemunduran. Moralitas pegawai-pegawai VOC mulai menurun karena rendahnya kesejahteraan yang mereka terima. Praktikpraktik korupsi mulai marak dan menggerogoti pondasi kongsi dagang Hindia Belanda ini. Selain itu kas negeri Belanda juga sedang mengalami kekosongan akibat perang. Keuntungan VOC banyak tersedot untuk menutup kesulitan keuangan ini. Maka pada tanggal 31 Desember 1799, VOC yang hampir berusia dua abad harus menerima akhir hidupnya. Sejak 1 Januari 1800 kekuasaan di Hindia Belanda beralih dari VOC ke pemerintah kolonial Belanda.

Bubarnya VOC bukan berarti penderitaan negara jajahan berakhir. Eksploitasi terhadap kekayaan nusantara terus berlangsung. Sistem eksploitasi yang dilakukan VOC dengan pemerintah kolonial memiliki persamaan yaitu adanya penyerahan wajib hasil-hasil pertanian meskipun cara yang agak berbeda. Pemerintah kolonial mengadakan hubungan dengan para petani secara langsung dan lebih intens untuk menjamin arus tanaman ekspor dalam jumlah yang dikehendaki.

Golongan konservatif yang menguasai pemerintahan kolonial pada masa awal abad XIX memandang politik eksploitasi dengan penyerahan paksa peninggalan VOC sangat cocok untuk mengelola Hindia Belanda sebagai daerah wingewest atau daerah yang menguntungkan negara induk. Sistem penyerahan paksa itu dapat diterapkan dalam usaha eksploitasi produksi pertanian tanah jajahan yang langsung ditangani oleh pemerintah kolonial. Eksploitasi produksi pertanian yang dilakukan oleh pemerintah kolonial ini diwujudkan dalam bentuk perkebunan negara. Sejak itulah Hindia Belanda memasuki masa sistem tanam wajib atau tanam paksa (cultuurstelsel).

Sistem tanam paksa dilaksanakan melalui alat birokrasi pemerintah yang berfungsi sebagai pelaksana langsung dalam proses mobilisasi sumber perekonomian berupa tanah dan tenaga kerja.Sistem tanam paksa lebih mengutamakan peningkatan hasil produksi tanaman ekspor yang sangat laku di pasaran Eropa. Untuk itu pemerintah kolonial memperkenalkan tanaman ekspor kepada petani di Jawa. Pelaksanaan tanam paksa dalam kenyataannya tidak sesuai dengan peraturan yang berlaku pada masa itu. Sistem tanam paksa lebih menguntungkan pemerintah kolonial dan semata-mata sebagai bentuk eksploitasi (Robert van Niel dalam Anne Booth,dkk., 1988:101).

Meskipun dapat ditarik suatu konklusi secara umum bahwa sistem tanam paksa membawa penderitaan, akan tetapi sistem tanam paksa membawa dampak besar bagi perubahan sosial ekonomi petani Jawa. Subsistensi yang sejak dulu menjadi warna dalam perekonomian petani Jawa mengalami pergeseran. Secara perlahan namun pasti sistem tanam paksa telah memperkenalkan perekonomian uang yang kemudian semakin berkembang dengan masuknya modal asing dalam koridor ekonomi liberal.

\section{METODE}

Metode yang digunakan dalam penelitian ini adalah dengan studi literatur dengan analisis deskriptif kualitatif. Pembahasan akan difokuskan pada sejarah kemunculan sistem tanam paksa dan penyimpangan-penyimpangan yang terjadi dalam pelaksanaannya, serta dampak system tanam paksa pada petani Jawa pada kurun waktu 1830-1870.

\section{HASIL DAN PEMBAHASAN}

Pemerintah kolonial Belanda yang pertama kali setelah runtuhnya VOC dipimpin oleh 
Dirk van Hogendorp (1799-1808). Dalam pemikiran kaum liberal kondisi rakyat yang tertinggal disebabkan oleh sistem feodal yang mematikan potensi rakyat. Hogendorp mengusulkan agar kedudukan bupati dan penguasa lokal diatur kembali, penguasaan tanah dicabut dan dikembalikan pada rakyat untuk ditanami secara bebas (Sartono Kartodirdjo, 1993:290). Rakyat bebas memilih jenis tanaman dan menjualnya. Penyerahan wajib (verplichte leveranties) dalam bentuk pajak berupa hasil bumi dan uang kepala. Sistem ini diharapkan mendorong rakyat lebih giat menanam dan menghasilkan beras, kopi, lada, kapas, coklat, dan minyak kelapa untuk ekspor.

Pasca penguasaan Inggris di Hindia Belanda (1811-1816), pemikiran ekonomi politik di daerah jajahan mulai bergeser dari politik liberal ke pihak konservatif (Sartono Kartodirdjo, 1993:305). Sistem pajak tanah dan perkebunan bebas selama tiga puluh tahun banyak mengalami hambatan. Struktur sosial yang sangat feodal di Jawa menjadi pemicu utamanya. Pada waktu sistem pajak tanah diberlakukan (1810-1830) dan sistem penyerahan wajib di Jawa dihapuskan, daerah Priangan menjadi daerah perkecualian. Preanger Stelsel berupa wajib tanam kopi yang dilaksanakan di daerah Priangan membawa keuntungan besar bagi Belanda. Hal ini kemudian menjadi pilot project bagi pelaksanaan sistem tanam paksa yang dicetuskan oleh van den Bosch.

Johannes van den Bosch, diangkat sebagai Gubernur Jenderal Hindia Belanda pada tahun 1830 sebagai pengganti Du Bus de Gisignies. Bosch mendapat tugas untuk meningkatkan produksi tanaman ekspor yang tidak dapat dicapai oleh pemerintahan sebelumnya. Tugas ini sangat mendesak, karena keadaan keuangan di negara Belanda sangat parah.Satu-satunya jalan terbaik untuk menyelesaikan beban utang negara yang besar itu ialah memanfaatkan kekayaan di daerah jajahannya, Hindia Belanda. Solusi yang dicetuskan oleh Bosch ialah pelaksanaan sistem tanam paksa (Cultuurstelsel).

Sejak tahun 1830, sistem tanam paksa mulai diterapkan sebagai upaya menghidup- kan kembali sistem eksploitasi dari masa VOC yang berupa penyerahan wajib. Ikatan feodal dan hubungan patron-klien menunjukkan masih adanya pengaruh yang kuat. Maka Bosch memandang bahwaproses peningkatan produksi tanaman ekspor dapat dilakukan melalui pemulihan sistem penyerahan wajib.

Sistem tanam paksa merupakan penyatuan antara sistem penyerahan wajib dengan sistem pajak tanah. Ciri pokok sistem tanam paksa terletak pada kewajiban rakyat untuk membayar pajak dalam bentuk hasil tanaman pertanian merekadan bukan dalam bentuk uang seperti yang berlaku dalam sistem pajak. Pungutan pajak dalam bentuk barang (in natura) akan membuat produksi tanaman perdagangan (cash crops) dapat dikumpulkan dalam jumlah besar. Produksi tanaman ekspor yang berhasil dikumpulkan itu, diharapkan akan dapat dikirimkan ke negeri induk, yang kemudian dipasarkan di pasaran dunia secara luas, baik di Eropa maupun Amerika. Pemasaran produksi tanaman ekspor di pasaran dunia itu akan mendatangkan keuntungan besar baik bagi pemerintah maupun para pengusaha di negeri Belanda, sehingga utang negeri induk segera dapat dibayar (Sartono Kartodirdjo dan Djoko Suryo, 1991:54).

Dalam pelaksanaan sistem tanam paksa, van den Bosch menghendaki peningkatan campur tangan orang Eropa dalam proses produksi. Rakyat dipaksa menanam tanaman ekspor yang diminta pemerintah di tanahtanah milik mereka sendiri.Penyerahan hasil tanaman, menurut teorinya, dilakukan atas kemauan penduduk sendiri namun tentu dalam kenyataannya tidaklah demikian. Tuntutan kerja paksa (kerja rodi) atau pekerjaan tanam paksa diwajibkan bagi penanaman kopi yang hampir semuanya dilakukan di tanah yang belum digarap, meskipun pada praktiknya penanaman juga dilakukan di lahan pertanian yang sudah digarap.

Dalam teorinya sebagai upah atas penanaman tanaman yang diminta pemerintah maka penduduk dibebaskan dari kewajiban membayar pajak tanah. Pajak nantinya dipungut bukan dalam bentuk uang melainkan 
dalam bentuk in natura atau dengan memberikan tenaganya untuk bekerja. Hal ini dianggap lebih sesuai dengan sifat rumah tangga desa yang ingin dipertahankan sebagai rumah tangga produksi dan dicegah agar tidak menjalankan rumah tangga uang (Sartono Kartodirdjo dan Djoko Suryo, 1991:55).

Tujuan pelaksanaan sistem tanam paksa mengikuti pola kekuasaan tradisional masyarakat Jawa. Kaum tani digerakkan untuk bekerja menghasilkan tanaman ekspor. Untuk itu diharapkan para kepala desa dan birokrasinya mampu menggunakan kekuasaan mereka untuk menggerakan orang-orang bekerja dengan cara baru. Masyarakat desa dipaksa menyerahkan pemakaian sebagian tanah mereka untuk penanaman tanaman keperluan pemerintah dan sebagian besar masih untuk menanam padi keperluan masyarakat. Tujuannya ialah agar masyarakat Jawa tetap statis secara ekonomi agraris (Robert van Niel dalam Anne Booth, dkk., 1988:116). Kenyataannya hal ini tidaklah demikian.

Sasaran pokok dari sistem tanam paksa yaitu memperoleh produksi setinggi-tingginya. Sasaran ini justru menimbulkan banyak terjadi penyimpangan di lapangan yang menimbulkan tekanan berat terhadap rakyat pedesaan. Penyimpangan ini didasari pada "kejar setoran" yang dilakukan oleh para birokrat lokal. Sistem tanam paksa berjalan dengan berbagai kesukaran dan perlakuan yang menyakitkan terhadap kaum petani Jawa. Akan tetapi pada sisi lain pandangan sejarah makin lama makin mencoba memperlihatkan kerangka perubahan sosial-ekonomi masyarakat Jawa yang lebih luas(Robert van Niel dalam Anne Booth, dkk., 1988:104-105).

Aturan mengenai pelaksanaan sistem tanam paksa pada dasarnya masih dapat diterima karena masih berada dalam koridorkoridor kewajaran yang masuk akal. Permasalahannya ialah dalam praktiknya sistem tanam paksa menyimpang dari aturan yang ditetapkan. Menurut Sartono Kartodirdjo dan Djoko Suryo (1991:56) dalam Lembaran Negara (Staatsblad) tahun 1834, nomor 22, sistem tanam paksa dijalankan dengan ketentuan sebagai berikut :
1. Melalui persetujuan, penduduk menyediakan sebagian tanahnya untuk penanaman tanaman perdagangan yang dapat dijual di pasaran Eropa.

2. Tanah yang disediakan untuk penanaman tanaman perdagangan tidak boleh melebihi seperlima dari tanah pertanian yang dimiliki penduduk desa.

3. Pekerjaan yang diperlukan untuk menanam tanaman perdagangan tidak boleh melebihi pekerjaan yang dibutuhkan untuk menanam padi.

4. Bagian tanah yang ditanami tanaman perdagangan dibebaskan dari pembayaran pajak tanah.

5. Hasil tanaman perdagangan yang berasal dari tanah yang disediakan wajib diserahkan kepada pemerintah Hindia Belanda; apabila nilai hasil tanaman perdagangan yang ditaksir itu melebihi pajak tanah yang harus dibayar rakyat, maka selisih positifnya harus diserahkan kepada rakyat.

6. Kegagalan panen tanaman perdagangan harus dibebankan kepada pemerintah, terutama apabila kegagalannya bukan disebabkan oleh kelalaian penduduk.

7. Penduduk desa akan mengerjakan tanah mereka dengan pengawasan kepala-kepala mereka, dan pegawai-pegawai Eropa membatasi pengawasannya pada segi teknis dan ketepatan waktu dalam pembajakan tanah, panen, dan pengangkutan. Sistem tanam paksa dilaksanakan melalui saluran birokrasi pemerintah, yang melibatkan pejabat-pejabat pribumi dan Eropa. Pejabat pribumi mencakup para bupati hingga kepala desa.Pejabat Eropa meliputi para Residen, Asisten Residen, Kontrolir, dan Direktur Tanaman, yang bertugas sebagai pengawas jalannya pelaksanaan sistem tanam paksa.Ini berarti sistem tanam paksa menyandarkan diri pada sistem tradisional dan feodal dengan perantaraan struktur kekuasaan lama (Sartono Kartodirdjo, 1993:306). Sistem liberal yang sempat dianut berarti ditinggalkan sama sekali.

Jenis tanaman wajib yang diperintahkan untuk ditanam ialah kopi, tebu, dan indigo (bahan pewarna). Tanaman lain yang ikut 
ditanam dalam skala kecil, antara lain tembakau, lada, teh, dan kayu manis. Jenis tanaman itu ditanam pada seperlima bagian milik tanah penduduk, yang diminta secara paksa. Pada perkembangannya tidak hanya seperlima bagian namun bisa terjadi hampir seluruh tanah pertanian ditanami tanaman-tanaman wajib. Kopi lebih banyak ditanam di tanahtanah yang belum digarap, sehingga butuh pengerahan tenaga rakyat untuk membuka dan menggarap lahan tersebut. Maka dalam pelaksanaan sistem tanam paksa, penduduk masih diminta untuk menyerahkan tenaga kerja wajib atau kerja paksa (heerendiensten) untuk mengerjakan pekerjaan yang dibutuhkan pemerintah, seperti membuka lahan, pembuatan atau perbaikan jalan, saluran irigasi, pengangkutan dan berbagai pelayanan kerja lainnya. Menurut peraturan, kerja wajib dilakukan selama 66 hari dalam satu tahun (Sartono Kartodirdjo dan Djoko Suryo, 1991 :56).

Pelaksanaan sistem tanam paksa sebagian besar dilakukan di Jawa, hanya sebagian kecil di luar Jawa.Selain sebagai pusat kedudukan pemerintah kolonial Belanda, Pulau Jawa menjadi tempat pelaksanaan sistem tanam paksa yang paling berhasil dan paling disalahgunakan. Salah satu daerah di luar Jawa yang mengalami keberhasilan pelaksanaan tanam paksa yaitu Sumatera Barat berupa penanaman kopi (Kenneth R. Young dalam Anne Booth, dkk., 1988:136).

Sistem tanam paksa di Jawa dilaksanakan di daerah yang berada langsung di bawah pemerintahan administratif pemerintahan Hindia Belanda yang disebut dengan daerah gubernemen dengan perkecualian daerah Batavia (Jakarta), Bogor, dan daerah tanah partikelir (Partikuliere Landerijen). Daerah gubernemen tersebut mencakup 18 karesidenan, yaitu Banten, Priangan, Kerawang, Cirebon, Tegal, Pekalongan, Semarang, Jepara, Rembang, Surabaya, Pasuruan, Besuki, Pacitan, Kedu, Bagelen, Banyumas, Madiun, dan Kediri (Sartono Kartodirdjo dan Djoko Suryo, 1991:57).

Khusus untuk daerah praja kejawen (Vorstenlanden) yaitu Surakarta dan Yogyakarta tidak dikenai pelaksanaan sistem tanam paksa, yang berlaku ialah sistem persewaan. Di wilayah ini kemudian berkembang sistem tanah apanage yang disewakan karena tanam paksa dan perkebunan swasta membutuhkan lahan subur yang luas. Tanah apanage disebut juga tanah lungguh atau bengkok ialah tanah milik desa yang dijadikan upah atau gaji bagi priyayi atau bangsawan birokrat lokal (Suhartono, 1991:1). Para pemilik tanah apanage ini disebut bekel sebagai tuan tanah.

Tananam yang ditanam di setiap daerah tidak selalu sama, disesuaikan keadaan tanah setempat.Penyebabnya yaitu adanya perbedaan kondisi setempat terhadap kecocokan penanaman jenis tanaman yang ditentukan. Demikian pula keterlibatan penduduk dalam tanam paksa di daerah satu dengan daerah lainnya tidak sama. Selain terlibat dalam penanaman tanaman, penduduk masih terlibat dalam pengerahan kerja paksa.

Menurut Sartono Kartodirdjo dan Djoko Suryo (1991:59) terkait dengan pengerahan kerja paksa, ada tiga macam pelayanan, yaitu (1) kerja wajib umum (heerendiensten), mencakup pelayanan kerja untuk umum, seperti pembuatan atau perbaikan jalan, pembuatan gedung perkantoran, penjagaan tawanan, dan sebagainya, (2) kerja wajib pancen (pancendiesten), menyangkut tugas pelayanan kerja pertanian di tanah milik kepala-kepala pribumi, dan (3) kerja wajib garap penanaman (cultuurdiensten), menyangkut pengerahan kerja untuk membuka lahan perkebunan, pembuatan atau perbaikan irigasi, kegiatan penanaman, pengangkutan hasil panen dari lahan panenan ke tempat penimbunan (kopi, nila), atau ke pabrik pengolahan (tebu), dan kerja lain di perkebunan pemerintah.

Khusus untuk pengolahan tebu, dikerahkan tenaga penduduk sejak penanaman, pemotongan dan pengangkutan tebu, hingga proses penggilingan tebu di pabrik-pabrik gula.Pusat penanaman tebu pemerintah pada waktu itu paling banyak (hampir $65 \%$ ) di Jawa Timur, yaitu Pasuruan, Surabaya, dan Besuki.Daerah penanaman tebu lainnya yang luas ada di pesisir utara Jawa Tengah, yaitu Jepara, Semarang, Pekalongan, Tegal, dan juga 
termasuk Cirebon.Keuntungan yang banyak dari usaha gula, membuat swasta mengadakan kontrak dengan pemerintah untuk mengusahakan tanaman tebu. Pada tahun 1837, produksi gula dari swasta kira-kira separuh dari produksi gula pemerintah(Sartono Kartodirdjo dan Djoko Suryo, 1991 : 60).

Terkait dengan kerja paksa, A.M. Djuliati Suroyo dalam J. Thomas Lindblad (1998:217) mengungkapkan bahwa sebelum sistem tanam paksa diterapkan, jasa kerja paksa sudah dibutuhkan untuk pengerjaan tanahtanah apanage milik para bekel. Kerja paksa berfungsi memberikan pelayanan pribadi pada penguasa lokal, kerja untuk kepentingan umum, dan kerja untuk upacara adat (gugur gunung). Kondisi ini jelas berubah pada masa tanam paksa, tanah-tanah yang diklaim untuk tanam paksa kemudian dibagi untuk menciptakan pemilik tanah baru. Proses "petanisasi" ini menimbulkan pembagian beban kerja pula dan munculnya tenaga-tenaga bayaran yang mempengaruhi kehidupan ekonomi sosial masyarakat desa.

\section{Penyimpangan dalam Praktik Sistem Ta- nam Paksa}

Menurut yang tersirat dalam peraturan memang sistem tanam paksa tidak tampak memberatkan penduduk.Akan tetapi dalam praktik, banyak dilaporkan sebaliknya.Maka perlu dibedakan antara sistem tanam paksa dalam program pemerintah pusat dengan sistem tanam paksa dalam praktik di tingkat daerah.Penyelenggaraan sistem tanam paksa yang menggunakan pimpinan-pimpinan pribumi desa sebagai perantara, merupakan salah satu sumber petaka penyimpangan dalam praktik tanam paksa di tingkat desa.

Penyediaan tanah dan tenaga kerja cenderung dibebankan kepada seluruh desa, bukan pada penduduk secara individual sebagai pemilik tanah. Hal ini dilakukan dengan alasan untuk memudahkan penanganannya. Akibatnya timbul perluasan tanah yang sifatnya menjadi tanah komunal (milik bersama) serta terjadi perubahan hubungan sosial di pedesaan.

Sartono Kartodirdjo dan Djoko Suryo (1991:63) menjelaskan mengenai penyim- pangan tanam paksa khususnya pada pembagian tanah. Bagian tanah yang diminta untuk ditanami tanaman wajib melebihi dari $1 / 5$ bagian seperti yang ditentukan, misalnya sampai $1 / 3$ atau $1 / 2$ bagian, bahkan sering seluruh tanah desa.Demikian juga pembayaran setoran hasil tanaman banyak yang tidak ditepati menurut jumlah yang diserahkan, atau banyak kerja yang semestinya mendapat upah, tetapi tidak dibayarkan upahnya. Kegagalan panen dibebankan kepada penduduk. Pengerahan tenaga kerja perkebunan ke tempat-tempat yang jauh dari desa tempat tinggal penduduk, kerja rodi di pabrik-pabrik dan tempat lain tanpa upah yang tentu memberatkan penduduk.

Sartono Kartodirdjo dan Djoko Suryo (1991:63) juga memaparkan contoh kasus terkait dengan pengerahan tenaga kerja yang menyimpang. Di Rembang sebanyak 34.000 keluarga dipaksa untuk bekerja di lahan penanaman tanaman wajib selama 8 bulan dalam satu tahun, dengan upah rendah, yaitu tiga duit sehari. Contoh lain ialah sejumlah penduduk desa di Distrik Simpur, Priangan pernah dikerahkan untuk penanaman nila di tempat yang jaraknya jauh dari tempat tinggal mereka selama 7 bulan. Di distrik tersebut juga pernah dikerahkan 5.000 orang laki-laki dengan 3.000 ekor kerbau untuk mengerjakan tanah milik pabrik.

Para pegawai Belanda maupun para bupati dan kepala desa yang dapat menunaikan tugasnya dengan baik, pemerintah memberikan perangsang finansial, yang disebut cultuurprocenten (prosenan tanaman). Cultuurprocenten berupa persentase tertentu dari penghasilan yang diperoleh dari penjualan tanaman ekspor yang diserahkan para pegawai tersebut, jika mampu melampaui target produksi yang telah ditentukan pada setiap desa.Sementara penduduk memperoleh uang pembayaran upah tanaman (plantloon) komoditi ekspor.Pembayaran plantloon dimaksudkan agar penduduk mampu membayar pajak dan memiliki daya beli untuk barang-barang yang tersedia di pasar, terutama barang impor dari negeri Belanda.Pembayaran plantloon telah menyebabkan perluasan ekonomi uang ke lingkungan rumah tangga 
petani di pedesaan. Sistem tanam paksa telah menciptakan lalu lintas uang yang mempercepat timbulnya ekonomi uang di desa (Sartono Kartodirdjo, 1993:319).

Pemerintah semakin memahami akibat buruk dari penyimpangan sistem tanam paksa, terutama setelah terjadi banyak peristiwa kelaparan di beberapa daerah yang banyak membawa korban kematian dan penderitaan penduduk.Kritik dan gerakan untuk penghapusan sistem tanam paksa mulai dilancarkan.Mulai tahun 1860, sebagian besar tanam paksa dihapuskan. Secara bertahap tahun 1862 lada dihapuskan, 1865 nila, teh, dan kayu manis, dan tembakau pada tahun 1866.

Beberapa orang Belanda yang humanis seperti Eduard Douwes Dekker yang memiliki nama samaran Multatuli melancarkan kritik terhadap tanam paksa melalui tulisan yang berjudul "Max Havelaar". Berbagai kritikan awalnya tidak menyurutkan langkah pemerintah Kolonial Belanda dengan mengeluarkan Ordonansi Koelidan Poenale Sanctie pada tahun 1880. Dalam Ordonansi Koeli atau peraturan kuli ini terdapat Poenale Sanctie yaitu aturan yang memuat ancaman hukuman badan (kurungan dan pukulan) bagi kuli-kuli yang melanggar peraturan kerja (Jan Breman, 1997:xiv).

Tujuan utama dari aturan ini yaitu menjamin tenaga buruh bagi majikan, juga membatasi kemerdekaan buruh untuk meninggalkan perkebunan tempat bekerja.Perlakuan buruk terhadap buruh kerap terjadi misalnya seorang kuli (buruh) dipaksa bekerja dengan kekerasan dan diperlakukan sewenangwenang oleh majikan Belanda. Pukulan dengan rotan, penahanan, penelanjangan, dan bentuk-bentuk penyiksaan lainnya. Poenale Sanctie menambah kesengsaraan rakyat Indonesia dan memperpanjang daftar pelanggaran HAM yang dilakukan Belanda. Hal ini terus mendapat kecaman hingga pada tahun 1924, Majelis Rendah Belanda mengajukan protes atas Poenale Sanctie ini yag baru dicabut tahun 1941.

Sistem tanam paksa berhasil meningkatkan produksi tanaman ekspor, dan mengirimkannya ke negeri induk, dan kemudian dijual ke pasaran dunia, yang mendatangkan keuntungan besar.Dari tahun 1841-1863, sistem tanam paksa telah mendatangkan laba sebesar 461 juta, sehingga utang negeri Belanda dapat dilunasi.Antara tahun 18361866 diperoleh keuntungan sebesar 692 juta, dan antara 1867-1877 diperoleh 151 juta.Amsterdam berhasil menjadi pusat perdagangan dunia untuk komoditi tropis. (Sartono Kartodirdjo dan Djoko Suryo, 1991 : 65)

\section{Dampak Sistem Tanam Paksa bagi Petani Jawa}

Secara umum pelaksanaan sistem tanam paksa telah mempengaruhi dua unsur pokok kehidupan agraris pedesaan Jawa, yaitu tanah dan tenaga kerja.Akan tetapi menurut Robert van Niel dalam Anne Booth (1988 : 130), dampak dari sistem tanam paksa di Jawa selain mempengaruhi tanah (kemudian dikaitkan dengan sistem ekonomi pedesaan) dan munculnya tenaga buruh yang murah, masih ditambah satu hal lagi yaitu lahirnya pembentukan modal di desa. Perolehan laba yang sangat luar biasa bagi Belanda menunjukkan bahwa sistem tanam paksa merupakan eksploitasi Belanda, terutama di Jawa pada periode 1830-1870.

Sistem tanam paksa pertama-tama mencampuri urusan kepemilikan tanah penduduk pedesaan, karena petani harus menyerahkan tanahnya untuk penanaman tanaman ekspor.Tuntutan akan kebutuhan tanah pertanian untuk tanaman ekspor yang dilakukan dengan menggunakan ikatan desa, telah mempengaruhi pergeseran pemilikan dan penguasaan tanah di kalangan petani pedesaan. Hal ini dikarenakan adanya pertukaran atau pembagian tanah pertanian untuk perataan pembagian kewajiban penyediaan tanah dan kerja pada pemerintah, maupun adanya kecenderungan perubahan kepemilikan tanah perseorangan menjadi tanah komunal desa.

Menurut Robert van Niel dalam Anne Both (1988:118) menjelaskan bahwa sistem tanam paksa telah menghancurkan desa-desa di Jawa, karena telah memaksa mengubah hak kepemilikan tanah desa menjadi milik bersama dan dengan demikian merusak hakhak perorangan yang lebih dulu atas tanah. 
Hal ini menurut Clifford Geertz dalam teori involusi pertaniannya, mengakibatkan munculnya homogenisasi sosial di desa-desa Jawa yang mengakibatkan kemiskinan bersama (shared poverty).Hal inilah yang kemudian melahirkan sistem ekonomi pedesaan yang terus berlanjut meskipun sistem tanam paksa mulai memudar.

Selain tanah, sistem tanam paksa membutuhkan pengerahan tenaga kerja rakyat secara besar-besaran untuk penggarapan lahan, penanaman, pemanenan, pengangkutan, dan pengolahan di pusat-pusat pengolahan atau pabrik.Semua kerja yang dibutuhkan ini dilakukan dengan sistem kerja paksa. Pelaksanaan heerendiensten sangat memberatkan penduduk, karena selain tidak diberi upah, juga pekerjaan yang harus dikerjakan secara fisik cukup berat.Meskipun nantinya secara berangsur-angsur sistem kerja paksa di perkebunan diganti menjadi sistem kerja upah bebas.Sejak tahun 1837 mulai dilakukan individualisasi pekerjaan dalam perkebunan. Tahun 1855 sistem pekerjaan di perkebunan mulai teratur dan terspesifikasi.Pekerjaan di perkebunan maupun di sektor pembangunan mulai memberlakukan sistem kontrak. (Sartono Kartodirdjo dan Djoko Suryo, 1991 :67-68)

\section{Dari Ekonomi Subsisten ke Monetisasi}

Petani Jawa sejak awal terbentur oleh moral ekonominya yang subsisten. James C. Scoot (1981:26) menjelaskan bahwa petani menganut prinsip "utamakan selamat". Para petani lebih senang meminimalisir kemungkinan terjadinya suatu bencana (gagal panen) daripada meningkatkan penghasilannya. Dalam memilih bibit dan cara-cara bertanam para petani lebih menghindari risiko daripada melakukan spekulasi untuk meningkatkan penghasilannya. Untuk itulah petani lebih senang menanam tanaman pangan daripada tanaman perdagangan apalagi tanaman ekspor.

Sistem tanam paksa telah mengubah pola yang sejak dulu diyakini oleh para petani. Mereka dipaksa menanam tanaman ekspor untuk kepentingan ekonomi Belanda. Hal ini otomatis mengurangi produksi tanaman pangan mereka. Peralihan dari produksi subsistensi ke produksi komersil hampir selalu memperbesar risiko. Selain itu produksi komersil dalam sistem tanam paksa tidak menjamin persediaan pangan bagi keluarga. Akibat dari sistem tanam paksa maka memaksa petani untuk mengubah pola pikirnya.

Perubahan dalam sistem kerja juga telah mengenalkan sistem ekonomi uang (monetisasi) ke dalam lingkungan kehidupan pedesaan agraris (Sartono Kartodirdjo dan Djoko Suryo, 1991:68).Kehidupan perekonomian yang semula masih tradisional dan subsisten secara berangsur-angsur berkenalan dengan ekonomi uang melalui komersialisasi produksi pertanian dan pasaran kerja. Sistem tanam paksa telah menjadi pintu masuk peredaran uang ke daerah pedesaan. Sistem ekonomi uang ini membuat para petani mulai tergantung pada dunia luar. Produksi pertanian dirasakan sebagai komoditi untuk ekspor dan pasar dunia.Sistem ini mulai menggoyang sistem ekonomi subsisten sebagai ekonomi tradisional yang bersifat tertutup dan memenuhi kebutuhan rumah tangga sendiri bagi petani.

Suyatno Kartodirdjo dalam Robert van Niel (2003:ix) mengungkapkan bahwa teori dualisme ekonomi yang diajukan Boeke $(1942,1953)$ yang menyebutkan bahwa sistem ekonomi modern yang dipraktikan negara kolonial hidup berdampingan dengan sistem ekonomi tradisional (ekonomi subsistens) dan tidak saling mengganggu, tidaklah benar. Hal ini terbukti dengan munculnya resistensi petani, seperti Pemberontakan Petani Banten 1888, dan berbagai gerakan protes petani lainnya di Jawa abad XIX.

Menurut Sartono Kartodirdjo dan Djoko Suryo (1991:69) ada beberapa hal positif dari pelaksanaan sistem tanam paksa, antara lain terjadinya pembaruan dalam sistem administrasi pemerintahan desa akibat campur tangan pemerintah kolonial. Secara tidak langsung, pelaksanaan tanam paksa juga telah mengenalkan teknologi baru, terutama dalam pengenalan bibit-bibit tanaman perdagangan, seperti tebu, indigo, dan tembakau, beserta cara penanamannya. Selain itu, ka- 
rena tuntutan peningkatan produksi, maka diadakan perbaikan atau pembuatan irigasi, jalan, dan jembatan yang memperlancar transportasi dan komunikasi antar daerah. Dalam kehidupan sosial lainnya, pelaksanaan tanam paksa telah mendorong tumbuhnya usaha jasa angkutan di kalangan petani yang mampu, misalnya dengan pengadaan alat transportasi berupa gerobak atau cikar yang ditarik dengan ternak, seperti lembu, kerbau, atau kuda.

Mengenai pembentukan modal yang muncul akibat sistem tanam paksa, tentu tidak lepas dari perkembangan sistem ekonomi uang di desa.Dalam hal ini merupakan aspek yang lebih melibatkan orang Eropa dan Cina, daripada penduduk pribumi. Para kontraktor gula pemerintah merupakan pemimpin-pemimpin dalam pembentukan modal ini.Masuknya modal ini lebih didasari pada berkembangnya swasta yang sifatnya lebih liberal, dibandingkan sistem pemerintah yang berbelit-belit. Perkembangan modal swasta akan lebih tampak sesudah tahun 1880, ketika sistem tanam paksa betul-betul dibubarkan secara resmi(Robert van Niel dalam Anne Booth, 1988 : 131). Peralihan sistem tanam paksa ke sistem perusahaan swasta, sejajar dengan beralihnya kebijakan politik kolonial dari tangan kaum konservatif ke tangan kaum liberal yang menentang sistem eksploitasi oleh negara/pemerintah. Meskipun sistemnya berbeda, akan tetapi tujuannya sama yakni menggali sumber kekayaan tanah jajahan untuk keuntungan negeri Belanda. (Sartono Kartodirdjo dan Djoko Suryo, $1991: 72$ )

Pada akhirnya, sistem ekonomi modern yang muncul akibat tanam paksa meskipun berhasil mendorong Jawa makin terlibat dalam perdagangan internasional karena pertumbuhan yang mantap di bidang ekspor, namun di sisi lain telah mengeksploitasi habis-habisan sistem ekonomi subsistens yang menjadi basis ekonomi kaum tani. Eksploitasi lewat sistem tanam paksa bersifat brutal dan mengakibatkan petani Jawa menderita kemiskinan dan kelaparan. Struktur sosial dan ekonomi Jawa nyaris dihancurkan. Kemiskinan dan kelaparan menjadi masalah pokok penduduk Jawa. Teori involusi pertanian Clifford Geertz yang menjelaskan proses kemiskinan struktural di Jawa tampak relevansinya. Pertambahan penduduk Jawa, berkurangnya lahan pertanian dan perluasan perkebunan Eropa menjadi penyebab kemiskinan di Jawa.

\section{SIMPULAN}

Pada tahun 1930, negeri Belanda memiliki beban utang yang besar, karena itu mencari pemecahannya di daerah jajahannya, yaitu Indonesia.Pada masa ini juga mulai terjadi pergeseran pemikiran dari politik liberal ke politik konservatif. Maka gagasan pemecahan bagi masalah yang dihadapi Belanda bersumber pada kebijakan eksploitasi yang pernah diterapkan di Hindia Belanda. Sistem tanam paksa yang dicetuskan oleh van den Bosch memiliki tujuan utama yaitu meningkatkan produksi tanaman ekspor agar dapat menguasai pasaran dunia dan mendapat keuntungan sebanyak-banyaknya.

Sistem tanam paksa dijalankan dengan ketentuan tertentu yang diusahakan tidak merugikan kepentingan rakyat. Akan tetapi dalam praktik, banyak dilaporkan sebaliknya. Penyelenggaraan sistem tanam paksa yang memanfaatkan birokrat pribumi desa sebagai perantara, merupakan salah satu sumber penyimpangan dalam praktik tanam paksa di tingkat desa.

Secara garis besar dampak dari sistem tanam paksa di Jawa ialah selain mempengaruhi kepemilikan tanah dan munculnya tenaga buruh yang murah, masih ditambah satu hal lagi yaitu terjadinya pergeseran ekonomi petani Jawa. Pola pikir menghindari risiko mau tidak mau harus ditanggalkan karena tuntutan pelaksanaan sistem tanam paksa. Lahirnya pembentukan modal di desa dengan adanya sistem ekonomi uang (monetisasi) perlahan juga menyingkirkan sistem ekonomi petani Jawa yang sebelumnya bersifat subsisten.

\section{UCAPAN TERIMA KASIH}

Atas terlaksananya penelitian ini, kami mengucapkan terimakasih kepada: 
1. Dekan FKIP Universitas Sanata Dharma yang telah memberikan fasilitas berupa ijin pelaksanaan penelitian.

2. Bapak/ibu dosen Jurusan Pendidikan Sejarah Universitas Sanata Dharma yang telah memberikan masukan untuk kesempurnaan penelitian ini.

\section{DAFTAR PUSTAKA}

Breman, Jan. 1997. Menjinakkan Sang Kuli: Politik Kolonial, Tuan Kebun, dan Kuli di Sumatera Timur pada Awal Abad ke-20. Jakarta: Pustaka Utama Grafiti.

Djuliati Suroyo, A. M.. 2000. Tenaga Kerja di Jawa Sebelum dan Selama Sistem Tanam Paksa, hlm. 2130-1395.Dalam Thomas J. Lindblad (Ed). Sejarah Ekonomi Modern Indonesia: Berbagai Tantangan Baru.Jakarta : LP3ES.

Niel, Robert van. 1988. Warisan Sistem Tanam Paksa bagi Perkembangan Ekono- mi Berikutnya, hlm. 99-135. Dalam Anne Booth, dkk. (Eds).Sejarah Ekonomi Indonesia. Jakarta: LP3ES.

Sartono Kartodirdjo. 1993. Pengantar Sejarah Indonesia Baru: 1500-1900 Dari Emporium Sampai Imperium Jilid 1. Jakarta: Penerbit PT Gramedia Pustaka Utama.

Sartono Kartodirdjo dan Djoko Suryo. 1991. Sejarah Perkebunan di Indonesia: Kajian Sosial Ekonomi. Yogyakarta: Aditya Media.

Scott, James C.. 1981. Moral Ekonomi Petani: Pergolakan dan Subsistensi di Asia Tenggara. Jakarta: LP3ES.

Suhartono. 1991. Apanage dan Bekel: Perubahan Sosial di Pedesaan Surakarta (18301920). Yogyakarta: Tiara Wacana.

Young, Kenneth R.. 1988. Sistem Tanam Paksa di Sumatera Barat: Stagnasi Ekonomi dan Jalan Buntu dalam Politik, hlm. 136-164. Dalam Anne Booth, dkk. (Eds).Sejarah Ekonomi Indonesia. Jakarta: LP3ES. 